\title{
DIAGNOSIS THE EUROPEAN UNION'S LEGITIMACY CRISIS - DEMANDS FOR CHANGES
}

Tomasz KOWNACKI, PhD

University of Economics and Human Sciences in Warsaw, Poland

t.kownacki@vizja.pl

\begin{abstract}
The European Union has been in the midst of legitimacy crisis for several years. The author of the article diagnoses difficulties connected with the scientific analysis of this issue, indicating its causes, which arise from discrepancies in the definition bases, which constitute the initial assumptions for the research conducted so far. The article proposes new approaches, points out the current theoretical perspectives of the research and the resulting possibilities of overcoming the legitimacy crisis of the European Union. It also proposes to anticipate models for the legitimacy of the European Union on the basis of a synthesis of existing ones. The article diagnoses the causes for the difficulties, in search for an antidote for the European Union's legitimacy crisis.
\end{abstract}

Keywords: legitimacy, crisis, European Union, demands.

\section{Legitimacy, European Union, Crisis of Legitimacy. Theoretical Findings.}

\section{Conceptualizations}

In the literature on legitimacy, a range of terminological approaches to the term is presented. Considering its definition and interpretation, it should be noted that the research to date has applied parallels not only to the nation state but also to the international organization. Two perspectives of legitimacy were recognized as research directions - recognition and representation - which were variably important in individual scientific theories. The empirical-sociological school of thought focused on legitimacy in the perspective of recognition represented by M. Weber, D. Easton, M.S. Lipset, D. Beetham, J. Habermas, K. Deutsch, J. Steffek, W. Thaa, N. Woods (T. Kownacki, 2014, pp. 55-61) and the concepts of legitimacy derived from the theory of democracy considered the perspective of representation as the axis of consideration represented by J.J. Rousseau, J. Locke, R. Dahl, D. Held (T. Kownacki, op. cit. pp. 61-64). In the development of research concerning legitimacy, the various directions reinterpreted both approaches adapting them to the changing reality. "Treating" the issue as such seems to be the right approach - also for research on the legitimacy of the European Union. 
The European Union, which is a fact commonly recognized by many researchers (S. Hix 2010, T. Kownacki 2014 K. Tomaszewski 2013, J. Ruszkowski 2010, K. Szczerski 2008, A Wierzchowska 2008, K.A. Wojtaszczyk 2005) is neither a state nor a classical international organization $^{1}$. According to many researchers, it is a dynamic political system, which also has a number of specific features that distinguish it from classical political systems studied and defined in political science. The European Union should be seen as a unique, multi-level political system characterized by the coexistence and interaction of actors at regional, national and European levels (as well as various functional players, such as interest groups, etc.) N. Harrison's approach, which defines the political systems akin to the European Union as complex systems, seems to be correct. It consists of many actors interacting with each other, it is characterized by a decentralized decision-making process, it boasts features of openness, dynamics, dispersion, it obtains surprising results, and has many feedback loops (N. Harrison 2006, p. 7).

Thus, the existing concepts of legitimacy, either with regard to countries or international organizations, do not seem to be appropriate for examining EU legitimacy, also because of their static nature corresponding to well defined and recognized entities. To research the legitimacy of a dynamic structure such as the European Union, it is necessary - according to the author - to include it in both perspectives - representation and recognition treated in a complementary way.

It seems inappropriate to reject the achievements of classical theories and later thinkers dealing with the phenomenon of political systems' legitimacy simply because, as assumed in the publication, the European Union is a political system. In earlier concepts, both the recognition by the legitimizer and representation through voting were present, although not always called that way. For this study, the author proposes a definition, according to which "legitimacy is (...) a society's, or its significant circles, acceptance of the political system and its components" (L. Sobkowiak 1998, p. 154), while legitimization is a process of gaining recognition from EU citizens for representative actors involved in policymaking and implementation, leading to the legitimacy of the system.

The crisis of legitimacy is therefore understood as a disproportionate level of current acceptance (as shown, among other things, by public opinion surveys) concerning the activities of the European Union in relation to social expectations of the quality of its functioning, expressed

${ }^{1}$ The Treaty of Lisbon of 2007 formally describes the European Union as an international organization. 
by the citizens of the Member States. These definitions, which broadly interpret legitimacy, legitimization and the crisis of legitimacy, allow for a broader analysis of the studies phenomenon, surpassing the perspectives of singular, theoretical approaches. Due to the limitations of the topic, the author chose three of them: federalism, intergovernmentalism and constructivism.

The research hypothesis of the current article reads as follows: the crisis of legitimacy of a system as unique as the European Union is a process difficult to diagnose and alter, as evidenced by: problems in the unambiguous, universal, scientific definition of both the subject (the European Union) and the object of research (legitimacy); the variety of theoretical approaches to legitimacy which determine the different ways of stopping the crisis; the need to draw various theoretical models allowing to define a corrective perspective for the analyzed issue.

The Causes of the European Union's Legitimacy Crisis from a Theoretical Perspective: Federalism, Intergovernmentalism and Constructivism

This publication's definition of the legitimacy crisis allowed for an analysis of its causes in the context of particular theoretical approaches. A multifaceted and complex interpretation of the causes of the European Union's legitimacy crises arises.

The federal approach is characterized by the conviction that legitimization from EU citizens will ensure its EU's legitimacy and that citizen participation in decision making will allow them to control the process of their implementation and its results. A new entity would legitimize the European Union - an emerging European nation, shaped by common ethnic and cultural elements, i.e. common European culture, history, founding myths, traditions and common political values. The emergence of this new nation would be facilitated by European culture, characterized by permanence and unchangeability, which would give the EU citizens a sense of belonging, identity and roots (E Taasin 1992, p. 188). The aim should therefore be to create a homogeneous people at a European level, which would serve as the vehicle for sovereignty and the most important place for practicing democracy (Ch. Mouffe 2013, p.186). The federalists therefore call for the creation of a political community in which decisions relating to the entire European Union are publicly debated, where the European Parliament would be a forum for resolving conflicts and reconciling political interests in the established superstate of the United States of Europe. Seeing

the process of European integration as one which leads to the creation of a superstate, the federalists focus on the need to achieve firmly established European identity and the creation of 
supranational institutions responsible before citizens, ensuring a high level of legitimization for the European Union. Therefore, they see crises of legitimacy in the privileged and contested position of the nation state. This is evident in the statements of e.g. R. Menasse, who claims that the problems faced by the European Union today stem from that the EU is a union of nation states whose policies are driven by their own interests - at the expense of the interests of their societies. According to him, the current crisis, which has present since 2008, has the characteristics of a political crisis caused by the reluctance of national governments to create forms of democratic governance, which are essential for the European project. He believes that under the guise of representation and defense of national interests they defend the interests of small groups of national elites, who are influential because of their financial and economic strength (R. Menasse, 2013). In other words, nation states do not listen to the voice of their citizens or consider it when implementing policies in the European Union, which leads to a lack of sufficient legitimacy for their actions. Another, but equally important, trend that seriously reduces the level of legitimacy of the EU political system, which is in line with the federalist approach, was identified by Y. Mounk. According to him, the issue lies in the need to share sovereignty with the societies of those countries that are moving away from common European values by supporting the growth of European populism. According to Mounk, this applies to two countries - Poland and Hungary, whose governments are on course towards authoritarianism. The lack of effective action on the part of the European Union to change this state of affairs and to defend the democratic European values contributes to the increasing bitterness and dissatisfaction with the functioning of the political system. Mounk stated, that "The EU needs to make sure that the citizens of free countries will never have to share their sovereignty with the subjects of repressive dictatorships This calls for a much tougher response (from the EU institutions - author's note) to the authoritarian drift in many of its member states. Countries that violate the basic values on which the EU was founded need to lose their subsidies and their voting rights. If they don't correct course, there has to be a workable mechanism for suspending their membership" to ensure that the legitimacy regarding both the recognition and representation of the democratic nature of European Union governments and institutions, including, in particular, the European Parliament, will be increased (Y. Mounk 2020).

The intergovernmental approach assumes that the process of European integration is the result of struggle between sovereign states, and that the driving force behind the convergence 
towards integration is the preference of Member States rather than supranational institutions. Even if the current functioning of the European Union is implemented through supranational institutions, state actors initiate and control the integration process ${ }^{2}$.

According to the supporters of the intergovernmental approach, legitimacy crises are usually the result of integration processes being shifted to supranational positions (P. Borkowski 2013, p. 377), as well as mistakenly searching for it at a supranational level, rather than through member states. It is indicated that a crisis of legitimacy may mean that a state is ineffective in controlling the integration process or that it is unable to construct its own preferences and advocate for them in intergovernmental negotiations. It can also be the result of:

- the enlargement of the European Union to include new Member States, which in itself makes compromises difficult,

- the axiological difference between the new Member States - the countries of Central and Eastern Europe, which makes it difficult to find common ground within the Community,

- changes in the international system - globalization and processes related to it, which make the idea of how nation states should operate blurred,

- the disappearance of the determinants that led to the start of the post-war integration of Western Europe, the result of which is a "dilution" of the Community's identity.

- the weaknesses of the Member States' political elite, who "export" national issues to the EU and incorrectly formulate the preferences of their countries, consciously shifting the responsibility to the Union, when the aforementioned problems hinder the resolution of national problems.

- lack of implementation of redistributive policies by the EU, thus being left as individual responsibilities of member states, which makes overall activity of the EU invisible to regular citizens,

The financial crisis, which began in 2008, has provided more examples to supporters of intergovernmentalism in recent years ${ }^{3}$. Not only have supranational institutions not solved the

\footnotetext{
${ }^{2}$ Bruno Dallago and Stephen Rosefielde presented interesting ideas on the conditions and the paradox of the UK leaving, and Greece staying in the European Union (B. Dallago, S. Rosefielde 2019, p. 99-106)

${ }^{3}$ It is telling that the same crisis is also used as an example for supporters of supranationalism in the European integration process.
} 
problems of the Eurozone, they deepened them. Since the economic differences between Member States are significant and each of them is in a different macroeconomic situation, and the European Central Bank's uniform policy will not be beneficial to each country, inter-country decisionmaking would be a more effective mechanism for Union governance. At the same time, as P. Borkowski said, "as extraordinary measures had to be taken, it became apparent has the legitimacy and means to do so, as well as who - which institutions or bodies - is expected to formulate an answer to the challenge that was assessed as a threat to the entire integration process" ( $\mathrm{P}$. Borkowski, 2013, p. 350). In this critical situation, as P. Borkowski points out, it was nonetheless the Member States and not the EU institutions that were the focus of attention when looking for solutions to problems and formulating a strategic approach (see, aiding Greece).

The EU's legitimacy is in crisis as it was sought in the supranational political system and not through the Member States (so-called indirect legitimacy). For example, the legitimacy of saving or fiscal measures (or at least the absence of manifest opposition) is greater when they are implemented by democratically elected national politicians, rather than by countries forced by Brussels' Eurocrats ${ }^{4}$. If there is no democratic legitimacy in the European Union, the solution might lie in legitimacy resulting from the effectiveness of EU bodies (so-called utilitarian legitimacy). However, P. Borkowski expresses doubts as to whether citizens perceive this effectiveness and attribute it to EU bodies. (P. Borkowski 2013, p. 350). Z. Czachór, analyzing the arguments of the supporters of the intergovernmental approach, states: "heavy institutionalization, which includes more and more new areas of integration, leads not to freedom and a common European space, but to disfunctions in the $\mathrm{EU}$, and then to a reduction or even regression of integration" (Z. Czachór 2013, p. 142).

In both federalist and intergovernmental approaches, it is clear that the European Union's legitimacy is treated in the same categories as the legitimacy of the nation state as the finality of European integration. The advocates of intergovernmentalism build their model on the conviction that the driving force behind integration are states and their national interests. This model similar

\footnotetext{
${ }^{4}$ As an example of the weak legitimacy of decisions taken by the EU institutions, the view of Dan (2014) might be presented, who referred to the idea of imposing penalties for non-compliance with financial discipline on Member States. The Council of the European Union is not fulfilling its role of fiscal supervision in this respect, and the application of European law imposing possible penalties on Member States in the form of withdrawal of voting rights in the European Union institutions could seriously hamper the democratic, indirect participation of citizens in the democratic process of European integration along with other long-term adverse effects. (Dan, 2014, p. 78)
} 
to realism in international relations, which sees the European nation state as a strong, legitimated with political expression of universal sovereignty (P. Taylor 1996). Citizens give political legitimacy for two reasons: because they recognize and identify themselves with their nation state and because the state has democratically elected and functioning institutions. Thus, the responsibility for the legitimacy crisis lies with the democratic national institutions, which lose credibility and the sense of identification on the part of the EU member states citizens.

The Federalists look at the European Union as a superstate under construction and not as an organization of sovereign nation states. According to this model, legitimacy also depends on the creation of a universal European identity and on the central European institutions established at supranational level, responsible before the citizens of the European Union. The European identity, which is supposed to spread among the citizens of the European Union, consisting in a sense of common culture, awareness of history, political values, and identification with European institutions will, according to the federalists, strengthen the legitimacy of the system (H. Wallace 1993, p. 101). Similarly, according to K. Neureither, the development of institutions and their representativeness and accountability to citizens will have the same "legitimizing effect" ( $\mathrm{K}$. Neureither, 1994, p. 299 - 314). Supporters of both models, in their research adopting varied perspectives, diagnosed the crisis of legitimacy that emerged during the ratification of the Maastricht Treaty. They all saw a crisis of legitimacy in the institutions' lack of responsibility (European Commission) or feeble competences (European Parliament), which were supposed to weaken the legitimacy of European integration.

According to P.C. Schmitter, both the federal and intergovernmental approaches, although they highlight legitimacy from different perspectives, show it from the traditional positions of the state (P.C. Schmitter 1996, p. 132). They both treat the recognition of the European Union in terms of separate national and European identities, and representation only in terms of democratic central institutions. The intergovernmental approach to European integration builds identity with national institutions based on the shared history, culture and ethnicity of their citizens, which constituted, over the years, an intermediate form of legitimacy of the European Union. Political institutions are an expression of universal sovereignty derived from the consent of citizens, thus legitimizing the nation state which legitimizes the European Union. Such an approach indicates that its supporters refer to the original idea of the nation state, where institutions and shared identity are important. 
Those in favor of the federal approach argue that the European Union is legitimized to the extent in which a common European identity is developed among the citizens, and citizens' identity is based on shared historical and cultural experiences and on the extent to which the European institutions represent their interests. The state is an essential model and no other form of EU organization is considered. Only the strengthening of the institutions representing citizens' interests and the spread of the European identity is the right way towards increasing the legitimacy of the European Union. The goal of this model is to create a superstate. The crisis of legitimacy in their view is therefore caused by distortions in its gradual construction and in creation of a European identity to replace national ${ }^{5}$ identity.

Constructivist approach assumes that the progression or regression of the EU's legitimacy consists primarily of elements of discussion among the actors operating in its area (including its content and channels of communication). It recognizes, as the causes of the legitimacy crisis: the disturbances in the field of its regularity, scope and character, as well as in social perception. These are closely correlated with the identities of EU citizens as recipients of the crisis and participants that legitimize the EU. By analyzing the subject literature, one might conclude that there are currently several types of discourses that are sources of legitimacy for the European Union. At least six are distinguished:

1. the discourse of European bureaucracy;

2. the discourse of leaders at a European level;

3. the discourse of "utopian" Europeanism;

4. the discourse of the elites;

5. the discourse of national leaders on Europe;

6. the discourse of transnational political parties (J. Gaffney, 1999, pp. 304-306).

All of them have a number of flaws that cause legitimacy disturbances which cause the crises.

\footnotetext{
${ }^{5}$ It is worth noting that every identity requires basic values to refer to. Therefore, it is important to ask about the values on which European identity is to be based, so that it does not stand in opposition to the other, individual identities of an EU citizen. This could lead to a weakening of some at the expense of others as, which the federalists would like. After all, it cannot replace the values that are inherent to national identities, as this would probably lead to open conflicts and even wars within the multinational situation of the European Union. Therefore these values must be common and important enough for all Europeans to identify themselves with.
} 
The first discourse, taking place within the framework of European bureaucracy, is characterized by a detachment from a personal approach and a kind of monotony, resulting from the lack of any wit or humor. Its flaws lie in its form and tone. One might say these are "genetic" defects. This discourse's tone is reflected in the content and language of legal acts of various importance, and these do not stir up much excitement (e.g. rhetorical figures), and thus do not encourage action, reflection, or lively discussions, which are the driving force behind the legitimacy provided by discourse. For the European Union, the voice of bureaucracy must remain in the administratively required canons. The European Union, due to the flaws of this discourse, is seen as an incomprehensible and technocratic "heartless manipulator", with immense power, without interest in citizens' matters, free of responsibility and with a tendency to "tie hands" of national "enlightened statesmen" who struggle with the heartless machine of European bureaucracy. As Y. Mounk argues, the problem also lies in the fact that citizens are not interested in the discourse at this level and barely pay attention to it. They also do not think the discourse is actually needed. Mounk states that, "If many voters do not they possess influence over what is happening in their national capitals, the sense of impotence is even greater in the context of Brussels" (Y. Mounk 2020), which leads to disillusionment with the EU and a gradual acceptance of the more understandable arguments from the national arenas, which are served to gain the applause and support of Eurosceptics.

The second discourse is being pursued by European leaders at the transnational level. It may be expressed in with the following statement: European leadership is not lacking, but there is a lack of leadership which interacts with and is closely associated with leadership at the national level. This discourse is flawed because the relationships between leaders, political institutions, and voters are primarily purely national in nature, and thus the discourse between leaders at supranational level takes on the same character. This is caused by national conditions which dictate the subject of discourse and force thinking about Europe through the prism of national interest. These conditions make this discourse only secondarily intergovernmental or supranational in nature.

The third type of discourse called "Utopian" Europeanism is characterized by an enthusiastic pro-European style. The flaws of this type of discourse result from the rhetoric, which draws on the tradition of the movement from the 1930s, frequent references to the vision of the world at that time and the lack of effective discussions with the voters. 
The discourse of the elites - the fourth type - involves the leading media of most European countries, journalists and commentators, research centers, European universities, think tanks of most major political parties and intellectuals. The issue for the legitimacy of the European Union as well as its crisis in this type of discourse is the pursuit of a "cheap sensation" that lowers the quality of discourse on this level. The content of the proposed message also leaves a lot to be desired, especially the content of the information and its importance to the average EU citizen.

The fifth category of the discourse is an exception in the strongly pro-European rhetoric of its previous categories. Its actors are current or former statesmen. This discourse adopts the point of view of national interests and positions concerning the shape of the political integration process. Its nature is marked by a vision of Europe seen from the perspective of the common development of the European Union, a place occupied or to be occupied by a particular nation state represented by a leader.

The sixth type of discourse focuses on the level of transnational political parties - transEuropean political parties (J. Gaffney, 1999, pp. 304 - 306). The discourse involves the Christian Democrats, socialists and social democrats, liberals, communists, ecologists, regionalists and the so-called Newropeans (J. Ruszkowski 2010, pp. 148-153). A shortcoming of this discourse lies in its level of complexity - it is too high, not only between the families of political parties, but also within them. This is a result of the differences in their priorities, and in the interpretation of national values that the parties favor and on which they base their programs. Thee contemporary problem, and at the same time a challenge faced by European transnational political parties within the discourse and preventing legitimacy crises, is the capacity to develop a uniform position, a specific type of discipline among their members, a language or even a meta-language that suits all participants in the discourse and a certain degree of customary conduct.

\section{Prospects of overcoming the crisis of legitimacy of the European Union}

According to the characteristics of the above-mentioned theoretical perspectives of legitimizing the political system of the European Union to overcome its crisis, it is not easy to identify one universal remedy ${ }^{6}$.

\footnotetext{
${ }^{6}$ This is confirmed by Achim Hurrelmann, who claims that despite various discussions from different theoretical perspectives on the subject of legitimacy - the European Union - it has not yet been possible to find a consensus in this debate that would allow to draw clear conclusions accepted by researchers. (A. Hurrelmann, 2019),
} 
In the case of federalists, the answer to the crisis of legitimacy is an attempt to conceptualize the European Union in terms of "bottom-up federalism", which is the opposite of the "top-down federalism" that has so far dominated the justifications for the future shape of the European Union of the supporters of this approach. Massimo Cacciari is the precursor for this idea. Federalism proposed by Cacciari would recognize the unique, indigenous identity of different regions and cities, not for their isolation or separation from each other, but for creating the conditions for organized autonomy, realized on the basis of mutual exchange taking place in different areas in-between. Cacciari advocates for a new type of federal union, whose components will not be limited to states but will also include regions that play an important role. Such a Union would be characterized by autonomy in the framework of integrated systems on a conflict-related basis, including both the dimension of solidarity and competition. The European Union would not just be a demoicracy, consisting merely of nation states, a federation in which multiple demos exist and "practice" democracy on many levels and in various ways. As Ch. Muffe states, "such a vision recognizes and articulates different forms of collective identities, not only national but also regional. The growing importance of cities and new forms of cooperation is also recognized." Cacciri's concept also provides a geographical reference for the organization of regional units at the transnational level of the European Union, indicating the possibility of their coexistence in places where forms of cultural or economic unity already exist, for instance, in the border areas of Italy and Austria, Italy and France and France and Spain. The bottom-up federation assumes the importance of nations, indicating that there are also other important forms of loyalty and spaces for the democratic participation of EU citizens. It proposes that they should be able to participate in the whole complex and diverse range of demoi, enabling them to exercise their democratic powers without having to renounce their national, regional and local identities (Y.le Bot, M. Semo, A. Spandolini, 2001, p. 25-34).

In the two theoretical approaches presented further, the common causes of legitimacy crises emerge, for which greater involvement of political leaders in plans and their implementation for further stages of integration seems appropriate. Additionally, clear visions of the future shape of the European Union emerge, the European Union expresses itself clearly and comprehensibly, and the risks and benefits of its adoption and subsequent implementation are announced. This will allow citizens to understand and legitimize the actions planned and implemented at the transnational level of the European Union. 
The discourse of the European elites should be strengthened and should result from or complement that of the national level. Thanks to this dialogue, shaping of the European identity, which allows the EU political system to be considered "ours", will be the result of processes focusing on political actions, institutions and the EU legal system, all aiming towards pluralism of opinions, attitudes and behaviors. The final product of these should be the "space of common existence of the inhabitants of Europe", for which the institution of civil society is an opportunity (W. Wiktorska-Święcicka 2010, p. 160). If implemented correctly, EU citizens will be more likely than ever to demonstrate their legitimizing capabilities.

A necessary step and, at the same time, a challenge to strengthen the legitimacy of the EU political system is to change the (official) language of the discourse of the European bureaucracy into a more communicative and "to send" a message to EU citizens who currently do not understand or misunderstand it. This is a necessity dictated by the current crisis of the European Union, which has not only a financial but also a socio-communicative dimension. Opponents of the EU, including populists, utilize discourse which is easily digestible for EU citizens.

The crisis of legitimacy of the European Union is also an issue of nation states. In order to overcome the crisis, they should take steps to efficiently authorize their actions at the supranational level, not only by their representatives in the EU institutions, but also towards the citizens of these countries. An essential measure expected from their side is to clearly indicate the "added value" resulting from membership of the European Union not only for the countries but also for themselves. This utilitarian aspect of belonging to the EU is an important element which allows for the recognition of the value of the European Community, its benefits for citizens and its advantages. The diagnosis of the current crisis of legitimacy, which has been going on for more than a decade, suggests that to overcome it, the legitimacy of European national policies must increase. As advocates of intergovernmentalism stress, there can be no legitimacy of EU action if these policies are not legitimized at the national level. It is worth recalling that according to the intergovernmental theory, the Community is only a tool in the hands of the Member States.

As the above opinions show, the Union clearly needs a new vision. Restoration, in line with the intergovernmental approach, can come with a new proposition of measures to be taken, put forward by the Member States. This does not necessarily mean adopting a completely new identity, but perhaps a return to the vision ideas of the past, supplemented by new solutions. 
Table 1: Causes and proposals on how to overcome the crisis of legitimacy of the European Union from the perspective of constructivism, intergovernmentalism and federalism

\begin{tabular}{|c|c|c|}
\hline & Causes of the EU legitimacy crisis & Ways of overcoming the crisis \\
\hline $\begin{array}{c}\text { Constructivist } \\
\text { approach }\end{array}$ & $\begin{array}{l}\text { Disturbances or impairments in the } \\
\text { discourses: } \\
\text { 1. the discourse of European bureaucracy } \\
\text {; } \\
\text { 2. the discourse of leaders at a European } \\
\text { level; } \\
\text { 3. the discourse of "utopian" } \\
\text { Europeanism; } \\
\text { 4. the discourse of the elites } \\
\text { 5. the discourse of national leaders on } \\
\text { Europe; } \\
\text { 6. the discourse of transnational political } \\
\text { parties }\end{array}$ & $\begin{array}{l}\text { - Strengthened political leadership regarding } \\
\text { planning and implementation for further } \\
\text { stages of integration, creating a clear vision of } \\
\text { the future shape of the European Union, } \\
\text { clearly articulating it and communicating the } \\
\text { risks and benefits of its adoption and } \\
\text { implementation } \\
\text { - Strengthened discourse of the elites at the } \\
\text { supranational level resulting from and/or } \\
\text { complementing national discourses; } \\
\text { - changing the (official) language of the } \\
\text { European bureaucracy's discourse and } \\
\text { "reaching out" to EU citizens who currently } \\
\text { understand little or misunderstand it. }\end{array}$ \\
\hline $\begin{array}{c}\text { Intergovernmental } \\
\text { approach }\end{array}$ & $\begin{array}{l}\text { State inefficiency in controlling the } \\
\text { integration process has its roots in: } \\
\text { - the inability, by the states, to create own } \\
\text { preferences and to promote them in } \\
\text { intergovernmental negotiations } \\
\text { - the enlargement of the European Union } \\
\text { to include new member states; } \\
\text { - the axiological differences of the new } \\
\text { Central and Eastern European countries; } \\
\text { - changes in the international system - } \\
\text { globalization and the processes associated } \\
\text { with it; } \\
\text { - the disappearance of the determinants } \\
\text { that led to the start of post-war integration } \\
\text { of Western Europe; } \\
\text { - the weaknesses of the Member States' } \\
\text { political elite, who "export" national } \\
\text { issues to the EU and incorrectly formulate } \\
\text { the preferences of their countries, }\end{array}$ & $\begin{array}{l}\text { - Smooth authorization of state actions at } \\
\text { supranational level; } \\
\text { - clearly indicating the "added value" for } \\
\text { countries and citizens resulting from } \\
\text { membership in the European Union }\end{array}$ \\
\hline
\end{tabular}




\begin{tabular}{|l|l|l|}
\hline & $\begin{array}{l}\text { consciously shifting the responsibility to } \\
\text { the Union, when the aforementioned } \\
\text { problems hinder the resolution of national } \\
\text { problems. } \\
\text { - the lack of EU redistributive policies }\end{array}$ & \\
\hline Federalist & $\begin{array}{l}\text { - the reluctance of national governments } \\
\text { to create forms of democratic governance } \\
- \text { too few representative institutions } \\
\text { involved in decision-making processes in } \\
\text { the European Union }\end{array}$ & $\begin{array}{l}\text { - the creation of a European identity emerging } \\
\text { from other identities of European Union } \\
\text { citizens }\end{array}$ \\
& $\begin{array}{l}\text { European identity } \\
\text { - the disruptions in the process of building }\end{array}$ & $\begin{array}{l}\text { - the creation of new institutions to represent } \\
\text { a superstate - the United States of Europe }\end{array}$ \\
\hline
\end{tabular}

Source: Own elaboration

\section{Prediction of European Union legitimacy models}

From the theoretical analyses conducted, two model proposals for the legitimacy of the European Union emerge: representative and civic. One might present them in the following way:

The representative model would encompass strengthening indirect legitimacy. It should be organized through the creation of new institutions representing EU citizens located at different levels of the European Union, and by establishing new channels for representing their interests at European level, especially at the member state level. This would ensure that more interests of EU citizens are represented at the supranational level, and that the European identity of the institutions themselves is strengthened through the need to consider a wider range of their spectrum, which in turn would lead to a greater recognition and acceptance or disapproval of decisions by EU citizens, who would validate them by legitimizing the position taken by the institutional actors representing them, e.g. through elections at the national level. No well-established and universal European identity to replace national identity is required for this model. The existence of the former would possibly be the result of a multiplication of the remaining identities of European Union citizens. The local, regional and national interests represented by representative institutions at the supranational level in the process of confrontation and competition would emerge as solutions that are common or familiar. The decision-making mechanism would lead to the Europeanization of 
participants and the creation of their European identity. The decisions made as a result of competition of regional and national interests would generate validation from the legitimizing body, as well as create its European identity. For a high level of EU legitimacy, it would be appropriate to have as many representative actors as possible, resulting in the "cloud" effect in decision-making. In addition, the treaties should be made explicitly constitutional in order to "polarize", between the Union and nation state, the decision-making process, which has been weakened by the growing autonomy of the judiciary (European Court of Justice) and the executive body (European Commission) in democratic processes at the European level. This would be very difficult to achieve, requiring the treaties to be limited to provisions on the objectives of the EU, the powers of its institutions and their procedures and competences. All other provisions would be removed and transposed into national law, which, after BREXIT, does not seem impossible, at least for now.

The civic model would involve the strengthening of direct legitimacy by citizens. It would be the citizens of the European Union who would play a greater role in the formulation and expression of interests. They would have a direct impact on the institutions responsible for implementation of these interests. This model would assume the need to "remodel" the existing institutional framework. In this model, the European Parliament should originate from direct elections based on a uniform electoral law in force in all member states. Members of the parliament should be chosen from a European list agreed upon by the representatives of national political parties. This would allow the Parliament to pursue the European interests of EU citizens and not, as is the case now, the differently understood interests of the societies of the member states. The European Commission should gradually resign from its role as the "European governor" especially in those areas where it has fulfilled its role and where the European identity of EU citizens is clear and well established, such as gender equality or environmental policies. These areas should be considered by institutions managed by professionals chosen in the direct European elections (from a list of candidates-professionals, which could be presented, for example, by European interest groups) or appointed by the European Parliament (from similarly proposed lists of candidates). These candidates would then answer directly to the Parliament. The Council of Ministers of the European Union would remain as a counterbalance to the European Parliament, representing the national interest of each member state, and would be supported in its activities by their national parliaments and local and regional authorities. This model also assumes personal 
representation of interests and personal recognition by European Union citizens. This type of legitimacy in the literature is referred to as direct legitimacy. Citizens have three types of instruments to legitimize the EU political system. These include referendums, elections and the citizens' initiatives. Legitimacy through these tools is expressed in direct, collective or individual involvement in European affairs at the transnational level and does not require intermediary representatives to express their interests. Recognition or disapproval of the system may be expressed by the presence of EU citizens (their participation) in procedures allowing for direct decision-making, guaranteeing their direct influence on the shape and implementation of European policies and the shape of the political system itself (T. Kownacki, 2014, pp. 145 - 155, M. Thiel, O. Petrescu, 2017, pp. 9-39).

Both models put emphasis on the representation of citizens' interests by the institutions and their recognition, which can be expressed through the nature of multiple identities of EU citizens created through effective political discourse at various levels. The problem encountered by researchers and politicians, which requires in-depth reflection, lies in the creation of a decisionmaking mechanism which would allow for effective and efficient decision-making, expressing the multi-level identity of the legitimizer - the citizens of the European Union on the one hand, and ensuring the simplicity of this mechanism, which is understandable to citizens on the other.

\section{Conclusion}

Given the above analyses and findings, it must be considered that the hypothesis formulated at the beginning of the article has been positively verified in all three aspects. The crisis of legitimacy of a political system as unique as the European Union is a process difficult to diagnose. Changing it is equally difficult due to the research dilemmas in the selection and recognition of an unambiguous, universal definition of both the subject of legitimacy (the European Union) and the subject of research (legitimacy). The European Union continues to be analyzed using tools specific to the analysis of countries or international organizations, while it is neither a country nor a traditional international organization. The search for a coherent concepts for considerations steers the researchers towards political systems, and thus predestines them to formulate definitions of legitimacy appropriate to its character. Theoretical approaches to research on legitimacy burdened by the "original sin" of the defining the European Union in research, result in different diagnoses of the crisis of legitimacy and, consequently, ways of overcoming it. The above conditions make 
it difficult to indicate a universal, apt theoretical model that would make it possible to create a single antidote that would allow to implement the correct course of action, which would eliminate this crisis and a clear, and create an unquestionable corrective perspective.

This context leads to the conclusion that strategies to overcome the European Union's legitimacy crisis should be based on a synthesis of "prescriptions" given by scientists, with the ingredients of the "medicines" they contain being carefully selected in relation to current social expectations and the will and capabilities of the member states, operating in close cooperation with the institutions managing the political system of the European Union.

\section{References}

1. Borkowski P. J., (2013) Międzyrządowość w procesie integracji europejskie], Warszawa: Oficyna Wydawnicza Aspra-JR

2. Banchoff T., Smith M. P. (1999), Legitimacy and the European Union. The contested polity, London and New York: Routledge

3. Czachór Z. (2013), Kryzys i zaburzona dynamika Unii Europejskiej, Warszawa: Dom Wydawniczy ELIPSA

4. Dan H., (2014) The Euro Zone - between Fiscal Heterogeneity and Monetary Unity, Transylvanian Review of Administrative Sciences, No. 43, pp.68-84

5. Dallago B., Rosefielde S. (2019), The strange fate of Brexit and Grexit and the Eurozone: Integration and disintegration, Contemporary Economics, Vol. 13 No. 1, pp. 99-106

6. Gaffney J., (1999), Political rhetoric and the legitimation of the European Union, [in:] Banchoff T., Smith M.P. (Eds.), Legitimacy and the European Union. The contested polity, London and New York: Routledge

7. N. Harrison, (2006), Thinking about the world we make, [in:] N. Harrison, (Ed.) Complexity in World Politics, Concepts and Methods of a New Paradigm, New York: State University of New York Press

8. Hix S., (2010), System polityczny Unii Europejskiej, Warszawa: Wydawnictwo Naukowe PWN

9. Hurrelmann A., (2019), Legitimacy and European Union Politics, Summary and Keywords, Oxford University Press, available at 
https://oxfordre.com/politics/view/10.1093/acrefore/9780190228637.001.0001/acrefore9780190228637-e-1112, [accessed: 6.05.2020]

10. Kownacki T., (2014), Legitymizowanie systemu politycznego Unii Europejskiej, Warszawa: Dom Wydawniczy ELIPSA

11. Le Bot Y., Semo M., Spandolini A, (2001), The philospoher policican of Venice: Interviev with Massimo Cacciari, Soundings, No. 17

12. Menasse R., (2013), Demokracja nie musi być narodowa. Unia Europejska: pokój na kontynencie a oburzenie obywateli, Warszawa: Biblioteka POLITYKI,

13. Mouffe Ch. (2013), Przyszłość Europy. Podejście agonistyczne [in:] Co dalej z Niemiecką Europą? Krytyka polityczna. Wydanie specjalne, Vol 34, pp. 102 - 114

14. Neureither K. (1994), The Democratic Deficit of the European Union: Towards Closer Cooperation between the European Parliament and the National Parliaments. Government and Opposition Vol 29, pp. 299-314

15. Ruszkowski J., (2010), Parlament Europejski. Dynamika Instytucjonalna i Kompetencyjna, Szczecin: Uniwersytet Szczeciński

16. Ruszkowski J. (2010), Ponadnarodowość w systemie politycznym Unii Europejskiej, Warszawa: Wolters Kluwer Polska

17. Sobkowiak L. (1998), Legitymizacja polityczna, [in:] Jabłoński A. Sobkowiak L., (Eds.), Studia z teorii polityki, Wrocław: Wydawnictwo Uniwersytetu Wrocławskiego

18. Schmitter P.C. (1996), Examining the Future Euro-polity with the Help of New Concepts, [in]: Marks G., Scharpf F. W., Schmitter P.C., Streeck W. (Eds.), Governance in the European Union. London: Sage

19. Szczerski K. (2008), Dynamika systemu europejskiego.. Rozważania o nowym kształcie polityki w Unii Europejskiej, Kraków: Wydawnictwo Uniwersytetu Jagiellońskiego

20. Taasin E. (1992), Europe. A Political Community? [in:] Muffe Ch. (Ed.), Dimensions of Radical Democracy: Pluralism, Citizenship, Community, London - New York: Verso

21. Taylor P. (1996), The European Union in the 1990s., Oxford: Oxford University Press

22. Thiel M., Petrescu O. (2017), Institutional Instruments for Citizen Involvement and Participation: Their Impact on the EU's Political Processes and Institutional Legitimacy, [in:] Beatriz Pérez de las Heras (Ed.) Democratic Legitimacy in the European Union and Global Governance. Building a European Demos, Bilbao: Palgrave Macmillan 
23. Tomaszewski K. (2013), Unia Europejska w poszukiwaniu skutecznego mechanizmu zarządzania. Analiza krytyczna modelu teoretycznego multi-level governance, Warszawa: Wydawnictwo Adam Marszałek

24. Wallace H. (1993), Deepening and Widening: Problems of Legitimacy for the EC, [in:] Garcia S. (Ed.), European Identity and the Search for Legitimacy, London: Pinter

25. Wiktorska-Święcicka W., (2010), Europeizacja wartości demokratycznych w procesie kształtowania europejskiej tożsamości, [in:] Pocześniak A., Riedel R. (Eds.), Europeizacja, mechanizmy, wymiary, efekty, Torun-Wrocław: Wydawnictwo Adam Marszałek

26. Wierzchowska A., (2008), System Instytucjonalny Unii Europejskiej, Warszawa: Wydawnictwa Akademickie i Profesjonalne

27. Wojtaszczyk K.A., (2005), Instytucje w systemie politycznym Unii Europejskiej [in]: Wojtaszczyk K.A. (Ed.) System instytucjonalny Unii Europejskiej, Warszawa: Oficyna Wydawnicza ASPRA-JR. 